\title{
TINGKAT HIPEREMESIS GRAVIDARUM PADA IBU HAMIL TRIMESTER I DI KABUPATEN KENDAL
}

\author{
Triana Arisdiani ${ }^{\bowtie}$, Yuni Dwi Hastuti \\ Program Studi Ilmu Keperawatan Sekolah Tinggi Ilmu Kesehatan Kendal
}

\begin{tabular}{l}
\hline ARTICLE INFO \\
\hline Article history \\
Submitted : 2020-08-13 \\
Revised : 2020-08-14 \\
Accepted : 2020-08-20 \\
Keywords: \\
Hyperemesis Gravidarum \\
Pregnant \\
The First Trimester
\end{tabular}

\section{Kata Kunci:}

Hiperemesis Gravidarum Kehamilan

Trimester I

\begin{abstract}
Hyperemesis gravidarum occurs in pregnant women around the world, including in Indonesia. More than $80 \%$ of pregnant women in Indonesia experience excessive nausea and vomiting. This can lead to dehydration, electrolyte imbalance, or nutritional deficiencies that will even harm the mother and fetus. The purpose of this study was to determine the description of the hyperemesis gravidarum of pregnant women in the first trimester in Kendal Regency. Descriptive research design with a population of 94 respondents, namely all pregnant women with gestational age $0-12$ weeks who carry out pregnancy checks for a period of four weeks at the Polindes Nolokerto Village, Kaliwungu District, Kendal Regency. The number of samples in this study were 54 respondents. The research instrument used the Check List. Data analysis using percentages. The results showed that almost all respondents $(92.6 \%)$ had moderate hyperemesis gravidarum, and a small proportion (7.4\%) of respondents had mild hyperemesis. It can be concluded that most of the trimester 1 pregnant women have hyperemesis gravidarum. It is recommended that pregnant women and their families actively seek information regarding the handling of hyperemesis gravidarum.
\end{abstract}

Hiperemesis gravidarum terjadi pada wanita hamil diseluruh dunia termasuk di Indonesia. Lebih dari $80 \%$ wanita hamil di Indonesia mengalami mual dan muntah yang berlebihan. Hal tersebut dapat menyebabkan dehidrasi, ketidakseimbangan elektrolit, atau defisiensi nutrisi bahkan akan membahayakan ibu dan janinnya. Tujuan penelitian ini adalah untuk mengetahui gambaran hiperemesis gravidarum ibu hamil trimester I di Kabupaten Kendal. Desain penelitian deskriptif dengan jumlah populasi 94 responden yaitu seluruh ibu hamil dengan usia kehamilan $0-12$ minggu yang melakukan pemeriksaan kehamilan dalam jangka waktu empat minggu di Polindes Desa Nolokerto Kecamatan Kaliwungu Kabupaten Kendal. Jumlah sampel dalam penelitian ini 54 responden. Instrumen penelitian menggunakan check list. Analisis data menggunakan prosentase. Hasil penelitian didapatkan hampir seluruh responden $(92,6 \%)$ mengalami hiperemesis gravidarum sedang, dan sebagian kecil $(7,4 \%)$ responden mengalami hiperemesis ringan. Dapat disimpulkan bahwa sebagian besar ibu hamil trimester I mengalami hiperemesis gravidarum. Disarankan agar ibu hamil dan keluarga aktif mencari informasi terkait penanganan hiperemesis gravidarum.

Corresponding Author:

Triana Arsidiani

Program Studi Ilmu Keperawatan Sekolah Tinggi Ilmu Kesehatan Kendal

Telp. 089667888978

Email: arisdiani86@gmail.com

\section{PENDAHULUAN}

Hiperemesis gravidarum adalah mual dan muntah yang berlebihan pada wanita hamil sampai mengganggu pekerjaan sehari-hari karena keadaan umumnya menjadi buruk, karena terjadi dehidrasi (Mochtar, 2012). Hiperemesis gravidarum tidak hanya mengancam kehidupan wanita hamil, namun juga dapat menyebabkan efek samping pada janin seperti abortus, berat bayi lahir rendah, kelahiran prematur, serta malformasi pada bayi baru lahir (Verberg, Gillott, Al-Fardan, \&
Grudzinskas, 2005). Hyperemesis gravidarum, dilaporkan terjadi sekitar $0,5-2 \%$ dari semua kehamilan atau 5 - 20 kasus per 1000 dari seluruh kehamilan (Asih, Kampono, 2009). Sumber lain menyebutkan hiperemesis diperkirakan terjadi pada 5 per 1000 kehamilan (Birkeland et al., 2015).

Jumlah kejadian hiperemesis gravidarum mencapai $12,5 \%$ dari jumlah seluruh kehamilan di dunia (WHO, UNICEF, 2015). Ibu hamil yang mengalami hiperemesis gravidarum mencapai $12,5 \%$ dari seluruh 
jumlah kehamilan di dunia dengan angka kejadian yang beragam yaitu mulai dari $0,3 \%$ di Swedia, 0,5\% di California, 0,8\% di Canada, $10,8 \%$ di China, $0,9 \%$ di Norwegia, 2,2\% di Pakistan, dan 1,9\% di Turki. Sedangkan angka kejadian hiperemesis gravidarum di Indonesia adalah mulai dari 1-3\% dari seluruh kehamilan (Masruroh \& Retnosari, 2016). Di Jawa Tengah terdapat 56,60\% ibu hamil dari 121.000 dengan hiperemesis gravidarum, dan di Kabupaten Jepara terdapat $50,21 \%$ ibu hamil yang mengalami hiperemesis gravidarum dari jumlah ibu hamil 26.231 (Depkes RI, 2018).

Etiologi hiperemesis gravidarum belum diketahui secara pasti, tidak ada bukti bahwa penyakit ini disebabkan oleh faktor toksik, juga tidak ditemukan kelainan biokimia, namun diduga dipengaruhi oleh berbagai factor yaitu faktor predisposisi misalnya primigravida, faktor organik dan psikologis (Maulana, 2008; Rahmawati, 2011). Berdasarkan studi pendahuluan yang telah dilakukan oleh peneliti, ditemukan $6(75 \%)$ dari 8 ibu hamil tri mester 1 yang sedang memeriksakan kehamilannya pada tanggal 28 Agustus 2019 mengeluhkan mual muntah sehingga memicu tidak nafsu makan. Berdasarkan fenomena atau masalah tersebut peneliti merasa tertarik untuk melakukan penelitian yang berjudul "Gambaran Hyperemesis Gravidarum Pada Ibu Hamil Tri Mester 1 di Kabupaten Kendal”.

\section{METODE PENELITIAN Jenis Penelitian}

Penelitian ini menggunakan metode kuantitatif dengan desain penelitian deskriptif survei. Menurut (Notoatmodjo, 2018), penelitian deskriptif adalah suatu metode penelitian yang dilakukan dengan tujuan utama untuk membuat gambaran atau deskripsi tentang suatu keadaan secara obyektif.

Sedangkan metode survei yaitu suatu cara penelitian deskriptif yang dilakukan terhadap sekumpulan obyek yang biasanya cukup banyak dalam jangka waktu tertentu (Notoatmodjo, 2018). Penelitian ini bertujuan untuk Penelitian ini bertujuan untuk mengetahui gambaran Hiperemesis Gravidarum pada Ibu Hamil Trimester I di Kabupaten Kendal Kabupaten Kendal.

\section{Populasi dan Sampel}

Jumlah populasi 94 responden yaitu seluruh ibu hamil dengan usia kehamilan $0-12$ minggu yang melakukan pemeriksaan kehamilan dalam jangka waktu empat minggu bulan September 2019 di Polindes Desa Nolokerto Kecamatan Kaliwungu Kabupaten Kendal.

Sampel dalam penelitian ini adalah 54 responden ibu hamil trimester I dengan usia kehamilan $0-12$ minggu. Teknik sampling yang digunakan dalam penelitian ini adalah accidental sampling yaitu proses pengambilan sampel yang dilakukan dengan mengambil kasus atau responden yang kebetulan ada atau tersedia di suatu tempat sesuai dengan konteks penelitian (Notoatmodjo, 2018).

\section{Pengumpulan Data}

Instrumen dalam penelitian ini terdiri dari kuesioner A untuk mengetahui karakteristik responden meliputi umur, tingkat pendidikan, pekerjaan dan paritas dan kuesioner B untuk mengetahui kejadian hiperemesis gravidarum. Sebelum digunakan, instrumen penelitian digunakan telah diuji validitas dan realibilitas oleh peneliti.

\section{Analisis Data}

Peneliti melakukan analisa univariat. Analisa univariat bertujuan untuk menjelaskan atau mendeskripsikan karakteristik setiap variabel penelitian. Analisa univariat pada umumnya hanya menghasilkan distribusi frekuensi dan persentase tiap variabel (Notoatmodjo, 2018).

\section{HASIL PENELITIAN Karakteristik Responden}

Berdasarkan tabel 1. sebagian besar responden mempunyai umur dengan resiko rendah sebanyak $51(94,4 \%)$ responden dan .resiko tinggi sebanyak $3(5,6 \%)$ responden. Pendidikan responden sebagian besar adalah SMA yaitu sebanyak $32(59,3 \%)$ responden dan sebagian kecil SD dan Diploma masing-masing $4(7,4 \%)$ responden. Sebagian besar responden bekerja sebagai pegawai swasta yaitu sebanyak $29(53,7 \%)$ responden dan hanya $1(44,4 \%)$ responden yang bekerja sebagai pegawai negeri sipil. Sebagian besar responden adalah primigravida yaitu sebanyak $32 \quad(59,3 \%)$ responden dan hanya $5(9,3 \%)$ responden multigravida. Sebagian besar responden $(92,6 \%)$ mengalami hiperemesis gravidarum sedang, dan sebagian kecil $(7,4 \%)$ responden mengalami hiperemesis ringan. 
Tabel 1. Distribusi Frekuensi menurut Umur, Tingkat Pendidikan, Pekerjaan, Paritas, dan Tingkat Hiperemesis Ibu Hamil Trimester I

\begin{tabular}{lcc}
\hline \multicolumn{1}{c}{ Karakteristik } & Frekuensi (n) & Persentase (\%) \\
\hline Umur (Tahun) & & \\
$\quad$ Resiko Rendah $(20-35)$ & 51 & 94,4 \\
Resiko Tinggi $(<20$ dan $>35)$ & 3 & 5,6 \\
Total & 54 & 100,0 \\
Pendidikan & & \\
SD & 4 & 7,4 \\
SMP & 14 & 25,9 \\
SMA & 32 & 59,3 \\
DIPLOMA & 4 & 7,4 \\
Total & 54 & 100,0 \\
Pekerjaan & & \\
Ibu Rumah Tangga & 24 & 44,4 \\
Pegawai Swasta & 29 & 53,7 \\
Pegawai Negeri Sipil & 1 & 1,9 \\
Total & 54 & 100,0 \\
Paritas & & \\
$\quad$ Primigravida & 32 & 59,3 \\
Secundigravida & 17 & 31,5 \\
$\quad$ Multigravida & 5 & 9,3 \\
Total & 54 & 100,0 \\
Tingkat Hiperemesis & & \\
Ringan & 4 & 7,4 \\
Sedang & 50 & 92,6 \\
Total & 54 & 100,0 \\
\hline
\end{tabular}

\section{PEMBAHASAN}

\section{Karakteristik Responden}

Umur

Hasil penelitian didapatkan bahwa sebagian besar responden mempunyai umur dalam kategori resiko rendah $(20-35$ tahun) yaitu sebanyak $51 \quad(94,4 \%)$ responden, sedangkan untuk kategori resiko tinggi $(<20$ tahun dan $>35$ tahun) yaitu sebanyak $3(5,6 \%)$ responden.

Usia seorang wanita pada saat hamil sebaiknya tidak terlalu muda dan tidak terlalu tua. Umur yang kurang dari 20 tahun atau lebih dari 35 tahun, berisiko tinggi untuk melahirkan. Kesiapan seorang perempuan untuk hamil harus siap fisik, emosi, psikologi, sosial dan ekonomi (Asrinah, 2017). Usia reproduksi yang sehat dan aman adalah 20 - 35 tahun (Gilly, 2010). Usia dibawah 20 tahun bukan masa yang baik untuk hamil karena organ-organ reproduksi belum sempurna, hal ini tentu menyulitkan proses kehamilan dan persalinan. Sedangkan kehamilan diatas usia 35 tahun mempunyai resiko untuk mengalami komplikasi dalam kehamilan dan persalinan yaitu seperti perdarahan, gestosis, atau hipertensi dalam kehamilan, distosia dan partus lama (Manuaba, 2012). Menurut asumsi peneliti usia dalam penilitian ini menunjukkan bahwa sebagian besar responden sudah siap untuk mengandung dan melahirkan.

Sesuai dengan penelitian AR, (2012) didapatkan hasil bahwa kelompok usia gestasi ibu yang beresiko mengalami hiperemesis gravidarum pada minggu ke $6-12$ adalah $92,3 \%$ dan pada minggu $13-24$ adalah $7,7 \%$ dari total sampel kasus penelitian yang ada hiperemesis banyak terjadi pada trimester pertama. Penelitian lain yang dilakukan oleh Puriati \& Misbah, (2014) mendapatkan hasil bahwa terdapat hubungan antara umur ibu dengan kejadian hyperemesis gravidarum di RSUD dr. Adjidarmo tahun 2011. Teori yang dikemukakan oleh Prawirohardjo, (2014), bahwa hamil pada usia muda merupakan salah satu faktor penyebab terjadinya hyperemesis 
gravidarum. Hasil penelitian (Muchtar, 2018) menunjukkan bahwa ada hubungan yang signifikan antara umur dengan kejadian hiperemesis gravidarum $(\mathrm{p}=0,000)$. Penelitian lain juga menunjukkan ada hubungan yang bermakna $(\mathrm{p}=0,001)$ antara Umur dengan kejadian Hiperemesis Gravidarum (Umboh, Mamuaya, \& Lumy, 2014). Hasil yang sama oleh Sumai, Keintjem, \& Manueke, (2014) didapatkan ada hubungan umur dengan kejadian Hiperemesis gravidarum.

Penelitian Safari, (2017) menunjukkan hasil yang berbeda bahwa tidak terdapat hubungan yang signifikan antara umur dengan hiperemesis gravidarum di RSUD H. Abd. Manan Simatupang Kisaran tahun 2017, p = $0,296>0,05$. Dari 2 responden berumur $<20$ tahun mengalami hiperemesis gravidarum dan tidak hiperemesis gravidarum masingmasing sebanyak 1 orang $(3,1 \%)$. Dari 27 responden berumur 20-35 tahun mayoritas mengalami hiperemesis gravidarum sebanyak $20(62,5 \%)$ orang. Dari 3 responden berumur $>35$ tahun mayoritas ibu tidak mengalami hiperemesis gravidarum sebanyak $2(6,3 \%)$ orang.

\section{Pendidikan}

Sebagian besar responden berpendidikan SMA yaitu $32 \quad(59,3 \%)$ responden. Pendidikan merupakan segala upaya yang direncanakan untuk mempengaruhi orang lain baik individu, kelompok, atau masyarakat, sehingga mempengaruhi seseorang termasuk juga perilaku seseorang dalam menerapkan pola hidup sehat (Notoatmodjo, 2007). Pendidikan dapat mempengaruhi seseorang termasuk juga perilakunya terhadap pola hidup terutama dalam memotivasi untuk sikap berperan serta dalam perubahan kesehatan. Makin tinggi pendidikan makin mudah menerima informasi, sehingga banyak pula pengetahuan yang dimiliki, sebaliknya makin rendah atau kurang pendidikan seseorang akan menghambat perkembangan sikap terhadap nilai-nilai yang baru diperkenalkan, sehingga pendidikan diharapkan mempengaruhi kemampuan seseorang dalam mengontrol hyperemesis gravidarum (Runiari, 2010).

Penelitian oleh Umboh et al., (2014) didapatkan bahwa ada hubungan yang bermakna $(\mathrm{p}=0,000)$ antara Pendidikan dengan kejadian Hiperemesis Gravidarum. Hasil yang sama didapatkan dalam penelitian Hertje Salome Umboh, Mamuaya, \& S.N.Lumy, (2013) bahwa ada hubungan yang bermakna (p
$=0,000)$ antara pendidikan dengan kejadian Hiperemesis Gravidarum. Hasil ini berbeda dengan penelitian Sumai et al., (2014) yang menyebutkan tidak ada hubungan antara pendidikan dengan kejadian Hiperemesis gravidarum.

\section{Pekerjaan}

Pekerjaan responden didapatkan sebagian besar bekerja sebagai pegawai swasta yaitu $29(53,7 \%)$ responden, kemudian sebagai ibu rumah tangga terdapat $24 \quad(44,4 \%)$ responden dan pegawai negeri sipil hanya terdapat satu $(1,9 \%)$ responden. Sebuah penelitian menyebutkan hiperemesis gravidarum dilihat dari status pekerjaan paling tinggi dialami oleh ibu hamil yang bekerja sebanyak 5 orang $(62,5 \%)$ (L. P. M. V. Putri, Wiradnyana, \& Darmayasa, 2019). Penelitian lain oleh Handayani \& Aiman, (2018) menyebutkan hasil uji chi-square untuk umur ibu dengan $\mathrm{p}$ value $(0,000)$, paritas dengan $\mathrm{p}$ value $(0,000)$, pekerjaan dengan $p$ value $(0,021)$ $<0,05$. Hal tersebut menunjukkan ada hubungan antara umur, paritas, dan pekerjaan dengan kejadian Hiperemesis Gravidarum. Salindri, (2020) menyebutkan karakteristik ibu hamil yang mengalami hiperemesis gravidarum di Klinik Rawat Inap dan Bersalin Prima Husada Batangharipada tahun 2017-2019 adalah ibu multipara, pekerjaan ibu rumah tangga (IRT) dengan rentan usia 20 -35 tahun.

Sebaliknya penelitian oleh Atika, Putra, \& Thaib, (2016) yang meneliti hubungan pekerjaan dengan hiperemesis gravidarum didapatkan bahwa ibu hamil yang tidak bekerja lebih berisiko mengalami hiperemesis gravidarum daripada kelompok ibu hamil yang bekerja. Hasil tersebut dapat dibuktikan dengan uji statistik bivariat (Chi square) yang menghasilkan $\mathrm{p}$ value $=0,021$ memiliki kesimpulan bahwa hasil bermakna atau terdapat hubungan antara pekerjaan dengan hiperemesis gravidarum diperolehhasil $\mathrm{PR}=0,266$ yang berarti bahwa peluang subjek ibu yang tidak bekerja akan mengalami hiperemesis gravidarum adalah 0,266 kalilebih besar dibandingkan dengan subjek ibu yang bekerja. Penelitian lain menunjukkan bahwa dari 66 responden yang tidak bekerja yang mengalami hiperemesis gravidarum sebanyak 44 orang $(66,7 \%)$ lebih banyak dibandingkan dengan responden yang bekerja sebanyak 3 orang $(25 \%)$ dari 12 responden. Hasil uji statistik dengan uji chi square diperoleh nilai 
$\mathrm{p}=0,010$ dengan nilai $\alpha 0,05(\mathrm{p}<\alpha)$, maka dapat disimpulkan bahwa ada hubungan yang signifikan antara pekerjaan dengan hiperemesis gravidarum (Sastri, 2017).

\section{Paritas}

Hasil penelitian didapatkan bahwa sebagian besar responden merupakan primigravida yaitu $32(59,3 \%)$ responden. Primigravida adalah seorang wanita yang baru pertama kali hamil, sedangkan Multigravida adalah seorang wanita yang telah beberapa kali hamil. Seiring persiapannya untuk menghadapi peran baru, wanita akan mengubah konsep dirinya supaya siap menjadi orang tua. Setelah bertahap berubah dari seseorang yang bebas dan berfokus pada diri sendiri menjadi seorang yang seumur hidup berkomitmen untuk merawat seorang individu lain. Pertumbuhan ini membutuhkan penguasaan tugas-tugas perkembangan tertentu, seperti halnya menerima kehamilan, mengidentifikasi peran ibu, mengatur kembali hubungan antara ibu dan anak serta antara dirinya dan pasangannya, membangun hubungan dengan anak yang belum lahir dan mempersiapkan diri untuk menghadapi pengalaman melahirkan (Saleem \& Bobak, 2005 \& Yuli Aspiani, 2018).

Kejadian hiperemesis gravidarum berdasarkan paritas responden didapatkan hasil bahwa sebagian besar responden primigravida terjadi hiperemesis gravidarum dibandingkan dengan secundigravida dan multigravida. Hal ini sesuai dengan teori yang menyatakan bahwa, mual dan muntah terjadi pada $60-80 \%$ primigravida dan $40-60 \%$ multigravida. Jumlah kehamilan $2-3$ (multi) merupakan paritas yang aman ditinjau dari sudut kematian maternal. Hal ini dikarenakan persiapan fisik ibu dalam menghadapi kehamilan sudah lebih matang dibandingkan dengan kehamilan pertama ibu (H, 2009).

Hal diatas didukung teori yang dikemukakan oleh (Mansjoer, Suprohaita, \& Setiowulan, 2008) bahwa sekitar 60-80\% primigravida dan multigravida mengalami mual dan muntah berlebih (hiperemesis gravidarum). Kejadian hiperemesis gravidarum lebih sering dialami oleh primigravida daripada multigravida, hal ini berhubungan dengan tingkat stres dan usia si ibu saat mengalami kehamilan pertama. Pada ibu primigravida faktor psikologik memegang peranan penting pada penyakit ini, takut terhadap kehamilan dan persalinan, takut terhadap tanggung jawab sebagai seorang ibu yang menyebabkan konflik mental yang dapat mempererat mual dan muntah sebagai ekspresi tidak sadar terhadap keengganan menjadi hamil atau sebagai pelajaran kesukaran hidup (Kuşcu \& Koyuncu, 2002).

Penelitian oleh R. K. Putri, Soesanto, \& Wahyuni, (2014) menunjukkan bahwa terdapat hubungan yang bermakna antara paritas dengan hiperemesis gravidarum dengan nilai $\mathrm{p}=0,029$. Penelitian lain yang dilakukan oleh Ochtarina (2016), juga didapatkan ada hubungan antara paritas dengan kejadian hiperemesis gravidarum ( $\mathrm{p}$-value $=0,017)$. Hasil penelitian lain oleh Atika et al., (2016) menunjukkan bahwa terdapat hubungan yang signifikan antara gravida dengan hiperemesis gravidarum di RSUD H. Abd. Manan Simatupang Kisaran tahun 2017, $\mathrm{p}=0,004<0,05$. Dari 9 responden primigravida mayoritas mengalami hiperemesis gravidarum sebanyak 6 orang (18,8\%). Dari 19 responden multigravida mayoritas mengalami hiperemesis gravidarum sebanyak 16 orang $(50,0 \%)$. Dari 4 responden grandemultigravida seluruhnya tidak mengalami hiperemesis gravidarum sebanyak 4 orang $(12,5 \%)$. Hasil penelitian yang dilakukan oleh Puriati \& Misbah, (2014) bahwa dari analisis bivariat yang dapat disimpulkan bahwa sebagian besar ibu hamil yang mengalami hiperemesis gravidarum terjadi pada kelompok primigravida sebanyak 57 ibu hamil (72,2\%), sedangkan ibu hamil yang tidak mengalami hiperemesis gravidarum sebanyak 80 ibu hamil $(50,6 \%)$. Hasil tersebut dapat dilihat dari hasil uji statistik dengan menggunakan Chi Square pada Alpha $=0,05$ didapatkan nilai $\mathrm{P}=0,002(\mathrm{p}<$ $0,05)$ yang berarti bahwa secara statistik terdapat hubungan yang bermakna antara paritas ibu dengan kejadian hiperemesis gravidarum di tahun 2011. Gravida adalah jumlah kehamilan (lengkap atau tidak lengkap) yang dialami oleh seorang perempuan, gravida diikuti oleh angka romawi atau diawali dengan bahasa latin (Primi, multi) yang menunjukkan jumlah kehamilan. Hasil penelitian Umboh et al., (2014) didapatkan ada hubungan yang bermakna $(\mathrm{p}=0,001)$ antara Paritas dengan kejadian Hiperemesis Gravidarum. Hasil yang sama didapatkan dalam penelitian Hertje Salome Umboh et al., (2013) yang menyebutkan ada hubungan yang bermakna $(\mathrm{p}$ $=0,001)$ antara Paritas dengan kejadian Hiperemesis Gravidarum. 


\section{Tingkat Hiperemesis Gravidarum}

Berdasarkan hasil penelitian sebagian besar responden $(92,6 \%)$ mengalami hiperemesis gravidarum sedang, dan sebagian kecil $(7,4 \%)$ responden mengalami hiperemesis ringan. Gambaran hiperemesis gravidarum tingkat sedang pada kehamilan yaitu klien akan mengalami dehidrasi akibatnya pasien tampak lemah, apatis, turgor kulit makin menurun, lidah kering dan kotor, mata tampak cekung dan sedikit ikterus (Asrinah, 2017). Responden dalam penelitian sebagian besar menyatakan dirinya pernah dirawat, diberikan cairan infuse karena tidak nafsu makan dan badan terasa lemas. Enam responden menyatakan pernah mengalami peningkatan suhu tubuh sehingga harus dirawat inap.

Penelitian Rofi'ah, Widatiningsih, \& Arfiana, (2019) menyebutkan partisipan pada penelitian ini menyatakan bahwa kejadian hiperemesis gravidarum diawali dengan mual muntah yang normal dan terus berlanjut. Mual muntah mulai terjadi pada usia kehamilan $6-8$ minggu. Mual biasanya terjadi pada pagi hari tetapi dapat pula muncul setiap saat dan malam hari dan menyebabkan gangguan pada pekerjaan sehari-hari.

\section{KESIMPULAN DAN SARAN}

Sebagian besar responden $(92,6 \%)$ mengalami hiperemesis gravidarum sedang, dan sebagian kecil $(7,4 \%)$ responden mengalami hiperemesis ringan. Bagi peneliti selanjutnya diharapkan dapat lebih meningkatkan penelitian terkait hiperemesis gravidarum dengan menggunakan metode yang lainya misalnya tentang faktorfaktor yang mempengaruhi kejadian hiperemesis gravidarum.

\section{DAFTAR PUSTAKA}

WHO, UNICEF, U. and the W. B. (2015). Trends in Maternal Mortality: 1990 to 2015,Trends in Maternal Mortality: 1990 to 2015. WHO, Geneva.

AR, A. C. Y. (2012). Hubungan Antara Karakteristik Ibu Hamil dengan Kejadian Hiperemesis Gravidarum di RSUD Ujung Berung Periode 2010-2011. Universitas Islam Bandung.

Asih, Kampono, D. P. (2009). Hubungan Pajanan Helicobacter Pylori dengan Kejadian Hyperemesis Gravidarum. Majalah Osbtetri Ginekologi Indonesia, Vol $33 \mathrm{No}(3)$.
Asrinah. (2017). Asuhan Kebidanan Masa Kehamilan. Salemba Medika.

Atika, I., Putra, H. K., \& Thaib, S. H. (2016). Hubungan Hiperemesis Gravidarum dengan Usia Ibu, Usia Gestasi, Paritas, dan Pekerjaan pada Pasien Rawat Inap di RSUP Dr. Moh. Hoesin Palembang. Jurnal Kedokteran Dan Kesehatan: Publikasi Ilmiah Fakultas Kedokteran Universitas Sriwijaya.

Birkeland, E., Stokke, G., Tangvik, R. J., Torkildsen, E. A., Boateng, J., Wollen, A. L., ... Trovik, J. (2015). Norwegian PUQE (pregnancy-unique quantification of emesis and nausea) identifies patients with hyperemesis gravidarum and poor nutritional intake: A prospective cohort validation study. PLoS ONE. https://doi.org/10.1371/journal.pone.0119 962

Depkes RI. (2018). Kementerian Kesehatan Republik Indonesia. Kementerian Kesehatan RI.

Gilly, A. (2010). Buku Ajar Kesehatan Reproduksi Wanita. EGC.

H, W. (2009). Ilmu Kebidanan. Cetakan ke-2 (4th ed.). Jakarta: Yayasan Bina Pustaka Sarwono Prawirohardjo.

Handayani, S., \& Aiman, U. (2018). Analisis Kejadian Hiperemesis Gravidarum (HEG) Berdasarkan Karakteristiknya. Babul Ilmi_Jurnal Ilmiah Multi Science Kesehatan.

Hertje Salome Umboh, Mamuaya, T., \& S.N.Lumy, F. (2013). Faktor-Faktor Yang Berhubungan Dengan Kejadian Hiperemesis. Jurnal Ilmiah Bidan.

Kuşcu, N. K., \& Koyuncu, F. (2002). Hyperemesis gravidarum: Current concepts and management. Postgraduate Medical Journal, 78(916), 76-79. https://doi.org/10.1136/pmj.78.916.76

Mansjoer, A., Suprohaita, W. W. I., \& Setiowulan, W. (2008). Kapita Selekta Kedokteran, Jilid 2 Edisi III. Media Aesculapius FKUI. Jakarta.

Manuaba. (2012). Ilmu Kebidanan, Penyakit Kandungan, dan KB. Ilmu Kebidanan, Penyakit, Kandungan, dan KB. https://doi.org/10.1055/s-2008-1043995

Masruroh, \& Retnosari, I. (2016). Hubungan Antara Umur Ibu Dan Gravida Dengan Kejadian Hiperemesis Gravidarum Di Rsud Ambarawa Kabupaten Semarang. MUSWIL IPEMI Jateng. 
Maulana, M. (2008). Cara Cerdas Menghadapi Kehamilan dan Mengasuh Bayi. Yogyakarta: Katahati.

Mochtar, R. (2012). Sinopsis Obstetri: Obstetri Fisiologi, Obstetri Patologi Jilid 1 (3rd ed.).

Muchtar, A. S. (2018). Hubungan Umur Dan Paritas Ibu Hamil Dengan Kejadian Hiperemesis Gravidarum. Jurnal Ilmiah Kesehatan Diagnosis.

Notoatmodjo. (2018). Metodologi Penelitian Kesehatan. Jakarta: Rineka Cipta. Notoatmodjo, S. (2018). Metodologi Penelitian Kesehatan. Jakarta: Rineka Cipta.

Notoatmodjo, S. (2007). Promosi Kesehatan \& Perilaku. Jakarta: Rineka Cipta.

Prawirohardjo, S. (2014). Ilmu kebidanan edisi keempat. PT Bina Pustaka Sarwono Prawirohardjo, Jakarta.

Puriati, R., \& Misbah, N. (2014). Hubungan Paritas Dan Umur Ibu Dengan Kejadian Hiperemesis Gravidarum Di Rsud Adjidarmo Rangkasbitung Tahun 2011. Jurnal Obstretika Scientia.

Putri, L. P. M. V., Wiradnyana, A. A. G. P., \& Darmayasa, I. M. (2019). Karakteristik ibu hamil dengan hiperemesis gravidarum di RSUP Sanglah Denpasar tahun 2017. Intisari Sains Medis. https://doi.org/10.15562/ism.v10i2.257

Putri, R. K., Soesanto, E., \& Wahyuni, D. (2014). Hubungan Paritas Dan Status Nutrisi Dengan Hiperemesis Gravidarum Pada Ibu Hamil Trimester I Di Rb "Nh" Kuwaron Gubug Kabupaten Purwodadi. Jurnal Kebidanan.

Rahmawati, E. N. (2011). Ilmu Praktis Kebidanan. Surabaya: Victory Inti Cipta.

Rofi'ah, S., Widatiningsih, S., \& Arfiana, A. (2019). Studi Fenomenologi Kejadian Hiperemesis Gravidarum pada Ibu Hamil Trimester I. Jurnal Riset Kesehatan. https://doi.org/10.31983/jrk.v8i1.3844
Runiari, N. (2010). Asuhan Keperawatan Pada Klien dengan Hiperemesis Gravidarum: Penerapan Konsep dan Teori Keperawatan. Jakarta: Salemba Medika.

Safari, F. R. N. (2017). Hubungan Karakteristik Dan Psikologis Ibu Hamil Dengan Hiperemesis Gravidarum di RSUD H. ABD. Manan Simatupang Kisaran. Wahana Inovasi.

Saleem, S., \& Bobak, M. (2005). Women's autonomy, education and contraception use in Pakistan: A national study. Reproductive Health. https://doi.org/ 10.1186/1742-4755-2-8

Salindri, Y. (2020). Karakteristik Ibu Hamil Yang Mengalami Hiperemesis Gravidarum Di Klinik Rawat Inap Dan Bersalin Prima Husada Batanghari Pada Tahun 2017-2019. Jurnal Kesehatan "Akbid Wira Buana."

Sastri, N. (2017). Analisis Kejadian Hiperemesis Gravidarum Pada Ibu Hamil di Bidan Praktik Mandiri Ellna Palembang Tahun 2017. Kebidanan, 5(2), 455-466.

Sumai, E., Keintjem, F., \& Manueke, I. (2014). Faktor-faktor Yang Berhubungan Dengan Kejadian Hiperemesis Gravidarum Di Rumah Sakit Umum Daerah Dr. Sam Ratulangi Tondano Kabupaten Minahasa Provinsi Sulawesi Utara. Jurnal Ilmiah Bidan.

Umboh, H., Mamuaya, T., \& Lumy, F. (2014). Faktor-Faktor Yang Berhubungan Dengan Kejadian Hiperemesis Gravidarum Di Puskesmas Tompaso Kabupaten Minahasa. Jurnal Ilmiah Bidan.

Verberg, M. F. G., Gillott, D. J., Al-Fardan, N., \& Grudzinskas, J. G. (2005). Hyperemesis gravidarum, a literature review. Human Reproduction Update. https://doi.org/10.1093/humupd/dmi021

Yuli Aspiani, R. (2018). BuKu Ajar Asuhan Keperawatan Maternitas. Jakarta : TIM. 